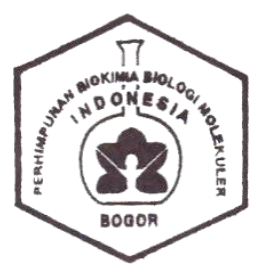

CURRENT BIOCHEMISTRY

ISSN: $2355-7877$

e-ISSN: 2355-7931

Journal homepage: http://journal.ipb.ac.id/index.php/cbj

Journal E-mail: current.biochemistry@gmail.com

\title{
Antibiotic-Resistant-Bacterial Infection of Diabetes Mellitus-Induced Ulcers: A Narrative Review on a Healing Ointment
}

\author{
Jaka Aryantara Kuntala ${ }^{1}$, Mutmainnah Agustiawan Umar $^{1}$, Qurrotu Ayni ${ }^{2}$, Dimas Andrianto ${ }^{1}$ \\ ${ }^{1}$ Department of Biochemistry, IPB University, Bogor, 16680, Indonesia \\ ${ }^{2}$ Department of Biology, IPB University, Bogor 16680, Indonesia
}

Received: 29 September 2020; Accepted: 16 December 2020

Corresponding author : Jaka Aryantara Kuntala; Departemen Biokimia IPB; e-mail: jaka_ak@apps.ipb.ac.id

\begin{abstract}
Gangrene is the main reason why diabetes mellitus patient's legs are amputated. Gangrene is a result of infection by bacteria such as Staphylococcus aureus. Natural compounds which are contained in coffee grounds extract, can actually act as antibacterial substances by inhibiting the growth of MethicillinResistant Staphylococcus aureus (MRSA) that is resistant to several antibiotics. Coffee grounds are discarded waste caused by people underusing this material, and there is a high production level of coffee grounds in Indonesia. The purpose of this study was to examine the content of antimicrobial compounds from coffee grounds that can heal wounds caused through hyperglicemia due to diabetes mellitus and to create a formulation of a coffee ground from based ointment for hyperglicemic-mediated infection. Methods used in this research are narrative review of the literature, normality tests, and T-tests. The conclusion of this narrative review is that natural compounds such a trigonelline, caffeine, and chlorogenic acid found in coffee grounds are capable of MRSA growth inhibition at a concentration of 44\%. A coffee grounds based ointment with $1 \%(\mathrm{w} / \mathrm{w})$ of ointment preparation is expected to reduce coffee grounds waste by developing a new product as for hyperglicemic-mediated wounding.
\end{abstract}

Keywords: Antibacterial, Coffee Grounds, Diabetes Mellitus, Gangrene, MRSA 


\section{INTRODUCTION}

Coffee is currently one of the most popular commodities. This is supported by the fact that coffee is one of the plantation commodities that has long been cultivated by Indonesians growers (Rahardjo 2012). Indonesia itself is ranked third largest in coffee production in the world (Sativa et al. 2014). According to the Badan Pusat Statistika (2017), coffee production in 2015 was about 602.37 thousand tons, then there was an increase in 2016 by 4.92 percent to 632 thousand tons and in 2017 this increased by 0.74 percent to 636.7 thousand tons. Along with increasing coffee production, coffee consumption among the community also increased. Coffee products that have been processed into beverages will produce coffee grounds. Although the amount of coffee that is produced is abundant, the resulting coffee is not presently being utilized further.

Coffee grounds are known to still have active ingredients that can accelerate wound healing. Even in the past Indonesians have used coffee grounds as an alternative for wound healing (Kumar et al. 2007). Research that has been done by Artho et al. (2015) supports the previous statement by pointing out that rabbits whose wounds are given coffee grounds are healing faster so that their level of inflammation can be lowered.

The Indonesian Ministry of Health in 2012 stated that diabetes mellitus is in the top ten non-contagious diseases with a large number of patients (Rosa et al. 2019). Patients with diabetes mellitus left without good selfmanagement, will develop into a more serious disease. In addition it can also cause complications such as the onset of gangrene. People with diabetes mellitus have a 29 times higher risk of gangrene. This is because diabetes mellitus are susceptible to infections closely related to the proliferation of bacteria in the environment with high glucose levels
(Wahyuni and Arisfa 2015). Diabetic ulcers are complications of diabetes consisting of deep tissue lesions associated with neurological and circulatory disorders especially in the lower limbs (Hajimohammadi et al. 2019). Chronic hyperglycemia as found in the case of diabetes mellitus often leads to secondary complications such as in blood vessels, kidneys, nerves, visual impairment and infections. Damage to blood vessels can cause blood flow to decrease, resulting in nerve damage to the legs. This can increase the likelihood of an ulcer in the foot (diabetic foot) (Scobie 2007). Bacterial infections that slow healing lead to deformity and death. Bacteria that cause infection in diabetic ulcers are Pseudomonas aureginosa, Streptococcus pyogenes, Staphylococcus aureus, Proteus mirabilis, Escherichia coli, and Klebsiella pneumoniae (Sutjahjo 2013).

Coffee has been shown to contain antimicrobial compounds, such as caffeine, trigonelline, glyoxal, methylglyoxsal, and chlorogenic acid. The bioactive substances can be obtained by extraction technique (Juliantari et al. 2018). According to Bonyanian and Rose'Meyer (2015), caffeine in coffee grounds can cure diabetic wounds. Antimicrobial compounds owned by coffee can inhibit the growth of Escherichia coli, Salmonella sp., and Staphylococcus aureus. Experiments have been conducted both in vivo and in vitro to test the activity of antimicrobial compounds contained in coffee (Matheson et al. 2011). The results of the experiment showed that coffee, or coffee grounds that still has the content of antimicrobial compounds, can provide antimicrobial or antibacterial benefits to wounds when applied topically. The use of these substances derived from coffee and coffe grounds can reduce the absorption of iron. It is important because iron is needed for the growth of Staphylococcus aureus (Matheson et al. 2011). 
Wounds caused by diabetes mellitus if not given proper treatment can lead to ongoing infections leading to amputation of limbs. There are several treatments for healing diabetes mellitus injury, which can be done by diabetic wound healing specialists, and drugs that can be smeared topically on the wound. However, such treatments are costly because drugs on the market are still relatively expensive. The use of antibiotics is not always effective in addressing this problem, as Methicillin-Resistant Staphylococcus aureus (MRSA) is still resistant to a number of antibiotics. In addition, coffee grounds have no economic value so are not utilized and just thrown away. Therefore, the use of coffee waste can be an alternative in treating wounds caused in diabetes mellitus.

\section{METHODOLOGY}

\section{Tools and Material}

This research used a narrative study method conducted on 44 papers. Tools used in this study are an ACER LAPTOP AS4739 and SPSS 16.0 software. The theoretical sources used in the study are:

1) the National Library of Medicine database site (http://www.pubmed.ncbi.nlm.gov)

2) Researchgate (http://www.researchgate.net)

3) web of science (https://www.webofknowledge.com)

4) Indonesian Scientific Repository (http://www.neliti.com/id/).

\section{Research Procedure}

The research procedure is described on Figure 1.

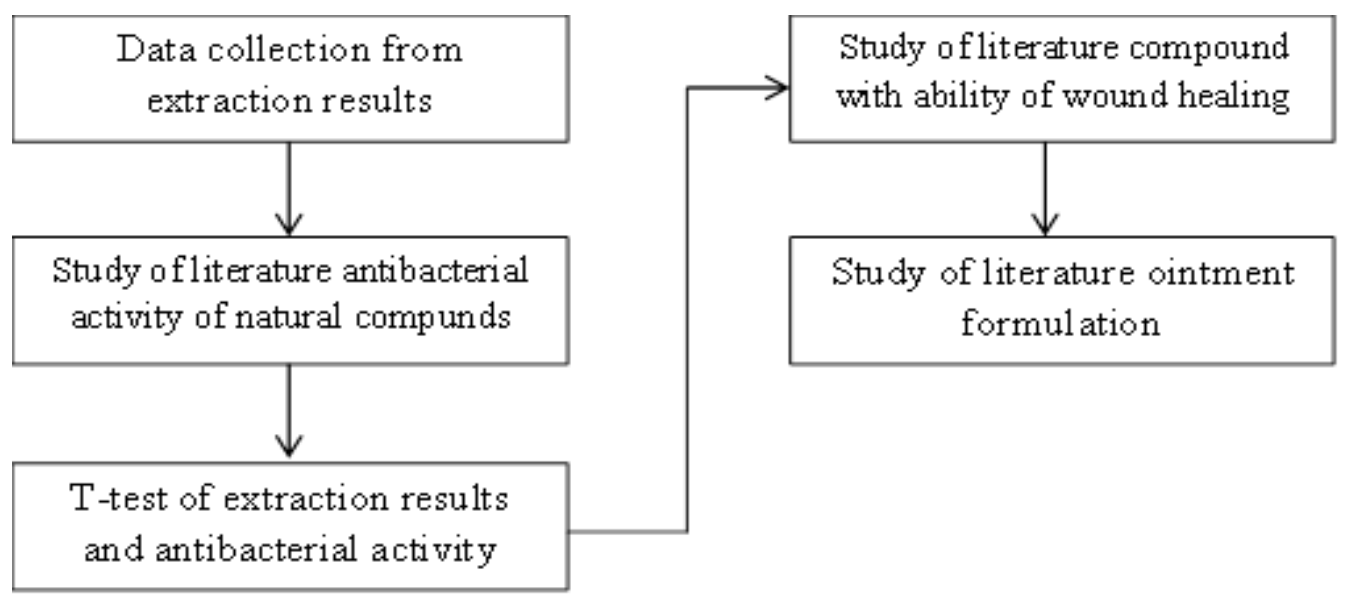

Figure 1. Research flow chart

\section{Normality Test Of Inhibition Capability Data (Apriyono 2013)}

Before the data from the concentration of robusta coffee compounds against bacterial resistance can be tested in $\mathrm{T}$ test, the variable that is in this study must be measured first to know the validity of the data with data normality test. Normality testing is performed to see the normality of the data used, whether the data is distributed normally or not. The normality of the data is very important because normal distributed data considered to represent the population. The test used is the Kolmogorov-Smirnov (Liliefor) test which is calculated with the SPSS 16.0 program.

\section{Paired T-Test of Robusta Coffee Compound} Content Against Two Types of Bacteria (modified from Hati and Novita 2018)

Once it was known that the data distribution is normal, the researchers used paired T-test analysis using the SPSS 16.0 
software. This analysis was used to determine significant differences between the resistance zone percentage of robusta coffee levels against wild type Staphylococcus aureus and Methicillin-Resistant Staphylococcus aureus. The testing criteria is to use a significant value /P-Value. If the value is significant /P-Value > 0.05 then Ho is accepted, whereas if the value is significant $/ \mathrm{P}-\mathrm{Value}<0.05$ then $\mathrm{Ho}$ is rejected and an $\mathrm{H}_{\text {alternative }}$ is accepted.

The coffee grounds based ointment used a modification of the method from Maya et al.(2017). The coffee grounds extract with the best concentration that can inhibit MRSA combined with white vaseline at concentration $1 \%(\mathrm{w} / \mathrm{w})$ was identified. The homogenization should be done by heating coffee ground extract with ethanol $96(\mathrm{v} / \mathrm{v})$, then ed to the white vaseline.

\section{RESULT AND DISCUSSION}

Chlorogenic acid is an antibacterial substance that works by permeability of plasma membranes enhancement so that the defense function of bacterial cells will decrease and bacterial cells may disrupt. Trigonelline also has antibacterial activity similar to chlorogenic acid, precisely by disrupting the stability of bacterial cytoplasmic membranes. Membrane instability will inhibit the exchange of bacterial nutrients so that metabolism and growth of bacteria becomes inhibited (Lee and Lee 2018). Caffeine is an alkaloid compound high in nitrogen in its base group so that it can react with cell wallbuilding amino acids and bacterial DNA. This damage causes genetic changes and lysis in bacteria (Tanauma 2016).

Table 1 Coffee extraction yield value results of various solvents

\begin{tabular}{|c|c|c|c|c|}
\hline Types of coffee & $\begin{array}{l}\text { Types of } \\
\text { treatment }\end{array}$ & Solvent types & Yield values & Sources \\
\hline Robusta coffee & Maceration & Ethanol $70 \%$ & $6.76 \pm 0.01 \%$ & Juliantari et al. (2018) \\
\hline Robusta coffee & Maceration & Ethanol $80 \%$ & $6.81 \pm 0.01 \%$ & Juliantari et al. (2018) \\
\hline Robusta coffee & Maceration & Ethanol $90 \%$ & $7.87 \pm 0.05 \%$ & Juliantari et al. (2018) \\
\hline Arabica coffee & $\begin{array}{l}\text { Soxhlet } \\
\text { extraction }\end{array}$ & n-hexane & $3.43 \%$ & Lamona and Nurman (2018) \\
\hline Arabica coffee & $\begin{array}{l}\text { Soxhlet } \\
\text { extraction }\end{array}$ & Ethanol $70 \%$ & $13.95 \%$ & Sri and Rubiyanti (2012) \\
\hline Arabica coffee & $\begin{array}{l}\text { Soxhlet } \\
\text { extraction }\end{array}$ & Ethanol $96 \%$ & $49.81 \%$ & Dewi et al. (2017) \\
\hline Robusta coffee & Maceration & Ethanol $96 \%$ & $10.80 \%$ & Wigati et al. (2018) \\
\hline Robusta coffee & Maceration & Ethanol $96 \%$ & $14.80 \%$ & Utami et al. (2018) \\
\hline Robusta coffee & $\begin{array}{l}\text { Sonication } \\
\text { extraction }\end{array}$ & Ethanol $96 \%$ & $20.50 \%$ & Utami et al. (2018) \\
\hline
\end{tabular}

The research of Juliantari et al. (2018) shows that from the results of diversity analysis, treatment of ethanol solvent concentration, maceration temperature and interaction between treatment has a very real effect $(\mathrm{P}<0.01)$ on robusta ground coffee rendment
(Coffea canephora L.). The results also showed that the highest yield were obtained by the treatment of $90 \%$ ethanol solvent concentration and $60^{\circ} \mathrm{C}$ maceration temperature in robusta coffee grounds extract, which is $7.87 \pm 0.05 \%$. The highest caffeine is 
obtained in this treatment with a rate of $0.70 \pm 0.01 \%$. The highest total phenol was obtained at $11052.83 \pm 1124.30 \% \quad \mathrm{mg}$ GAE/100g, while the lowest yield was produced at $70 \%$ ethanol solvent concentration treatment with a maceration temperature of $75^{\circ} \mathrm{C}$ of $5.27 \pm 0.02 \%$. The lowest levels of caffeine and phenols were obtained at $70 \%$ ethanol treatment with a maceration temperature of $45^{\circ} \mathrm{C}$, caffeine levels obtained amounted to $0.51 \pm 0.01 \%$, while phenol concentration obtained only $6449.62 \pm 54.28$ mg GAE/100g on this treatment.

In contrast to robusta coffee, arabica coffee oil rendment (Coffea arabica L.) from soxhlet extraction results with variations in extraction time, based on the data obtained, it appears that the optimal yield is produced at a time of 180 minutes which is $3.43 \%$ with the weight of the type of arabica coffee bean oil produced which is $0.9184 \mathrm{~g} / \mathrm{cm}$ (Lamona and Nurman 2018). In general, increased extraction time increases the number of yield. this is due to increased contact between samples and solvents (Aziz et al. 2009). Based on data obtained from GC-MS (Gas Chromatography-Mass Spectrometry), arabica coffee has several active compounds, six of which have an area above 4\% namely 2propanone,2.3-dimethyl butane 2chlorobutane, methyl cyclopentane, pentadecylid acid and 1.2benzenedicarboxylic acid (Lamona and Nurman 2018). Roasted arabica coffee beans have a caffeine content of 1.1-1.3 g/100 g, trigonellin levels of 1.2-0.2 g/100 g, and chlorogenic acid levels of 1.9-2.5 g/100 g (Farah 2012).

According to Sabarni and Nurhayati's research (2018), the temperature treatment and coffee roasting time will have a major influence on the types of compounds resulting from these processes. The roasting process is one of the important stages for producing thermally degraded compounds due to decaffeination. According to Ningsih (2014) caffeine in coffee can be obtained through extraction methods using organic solvents and extraction conditions are solvents, temperatures, time, $\mathrm{pH}$, and solvent compositions ratio with ingredients so as to affect the efficiency of caffeine extraction. Trigonelline obtained based on the research of Ky et al. (2001) with dekok extraction method and using distilled water as solvent is $1.77 \%$ for arabica coffee type, and $1.24 \%$ for robusta coffee type.

Mangiwa et al. (2015) show that the method and the temperature of the roasting step affect the levels of CGA or chlorogenic acid in coffee beans. CGA levels obtained from coffee beans range from $6,93-9.33 \%$ with the lowest chlorogenic acid levels obtained at a roasting temperature of $75^{\circ} \mathrm{C}$ and the highest obtained at a roasting temperature of $150^{\circ} \mathrm{C}$. The roasting process that is especially performed at temperatures above $180-200^{\circ} \mathrm{C}$ can result in major changes in the chemical compositions and bioligical activities of coffee as a result of Maillard and Strecker reactions (Belay and Gholap 2009). The selection of extraction methods will also affect the quality of the extract. The acidity level produced by the coffee extract becomes slightly higher with the soxhlet extraction method compared to the maceration method. Meanwhile, the chemical contents of coffee such as alkaloids, terpenoids, steroids, saponins, polyphenols and tannins in coffee beans extracted with soxhlet extraction method is higher than the maceration method. Therefore, it can be concluded that the extraction method affects the physical and chemical properties of coffee. The soxhlet extraction method is proven to be optimal in extracting coffee beans compared with the maceration method (Mangiwa et al. 2015). 
Table 2 Micronutrients level of Arabica and Robusta coffee extract

\begin{tabular}{|c|c|c|c|c|c|}
\hline $\begin{array}{l}\text { Types of } \\
\text { coffee }\end{array}$ & Micronutrients & Levels & Extraction Methods & Solvents & Sources \\
\hline \multirow{7}{*}{$\begin{array}{l}\text { Robusta } \\
\text { coffee }\end{array}$} & \multirow{4}{*}{ Caffeine } & $0.66 \pm 0.01 \%$ & \multirow{3}{*}{ Maceration } & Ethanol $70 \%$ & \multirow{3}{*}{$\begin{array}{l}\text { Juliantari et al. } \\
\text { (2018) }\end{array}$} \\
\hline & & $0.68 \pm 0.01 \%$ & & Ethanol $80 \%$ & \\
\hline & & $0.70 \pm 0.01 \%$ & & Ethanol 90\% & \\
\hline & & $84 \%$ & $\begin{array}{l}\text { Supercritical Protein } \\
\text { Extraction }\end{array}$ & $\mathrm{CO}_{2}$ and water & Tello et al. (2011) \\
\hline & \multirow[b]{2}{*}{$\begin{array}{l}\text { Chlorogenic } \\
\text { Acid }\end{array}$} & $1.346 \%$ & NADES-UAE & Water & \multirow{2}{*}{$\begin{array}{l}\text { Syakfanaya et al. } \\
\text { (2019) } \\
\text { Kaisangsri et al. } \\
(2019)\end{array}$} \\
\hline & & $99.21 \%$ & Maceration & Ethanol 95\% & \\
\hline & Trigonelline & $1.24 \%$ & Dekok extraction & Distilled water & Ky et al. (2001) \\
\hline \multirow{10}{*}{$\begin{array}{l}\text { Arabica } \\
\text { coffee }\end{array}$} & \multirow{3}{*}{ Caffeine } & $1.77 \%$ & Soxhlet extraction & Ethanol 96\% & Dewi et al. (2017) \\
\hline & & $57.83 \%$ & \multirow{2}{*}{$\begin{array}{l}\text { Liquid-liquid } \\
\text { extraction }\end{array}$} & \multirow[b]{2}{*}{ Chloroform } & Sabarni and \\
\hline & & $2.63 \%$ & & & $\begin{array}{l}\text { Suwiyarsa et al. } \\
\text { (2018) }\end{array}$ \\
\hline & \multirow{4}{*}{$\begin{array}{l}\text { Chlorogenic } \\
\text { acid }\end{array}$} & $9.33 \%$ & Soxhlet extraction & Methanol & $\begin{array}{l}\text { Mangiwa et al. } \\
\text { (2015) }\end{array}$ \\
\hline & & $5.07 \pm 1.0 \%$ & & Water & \multirow{3}{*}{$\begin{array}{l}\text { Sua' rez-Quiroz et } \\
\text { al.(2014) }\end{array}$} \\
\hline & & $4.67 \pm 1.6 \%$ & & Methanol 70\% & \\
\hline & & $5.28 \pm 1.2 \%$ & Maceration & $\begin{array}{l}\text { Isopropyl alcohol } \\
60 \%\end{array}$ & \\
\hline & $\begin{array}{l}\text { Chlorogenic } \\
\text { acid }\end{array}$ & $53.635 \%$ & & Ethanol 95\% & $\begin{array}{l}\text { Kaisangsri et al. } \\
\text { (2019) }\end{array}$ \\
\hline & Trigonelline & $0.96 \%$ & \multirow{2}{*}{ Dekok extraction } & \multirow{2}{*}{ Distilled water } & Yisak et al.(2018) \\
\hline & Trigonelline & $1.77 \%$ & & & Ky et al.(2001) \\
\hline
\end{tabular}

Before doing the Paired T-test, robusta coffee inhibition capability data on Staphylococcus aureus and MRSA bacteria were tested for normality first with Kolmogrov-Smirnov test to see whether or not the data spread was normal. After being tested, the data of the resistance of these two types of bacteria shows $\mathrm{p}$-value $>\alpha$, hence the $\mathrm{H} 0$ is accepted which means that both data sets spread normally. After that, a paired T-test can be conducted to see significant differences in robusta coffee inhibition capability to Staphylococcus aureus and MethicillinResistant Staphyococcus aureus bacteria. Result shows that this data has a p-value of $22.5 \%$ (p-value $>\alpha$ ) so H0 is accepted. This means there is no significant difference between Staphylococcus aureus and Methicillin-Resistant Staphylococcus aureus test results at a real rate of $5 \%$.

Coffee regulates the tissue condition by making wounds become acidic (Arimbi and Yuwono 2016). Areas of ulcers that are sufficiently acidic can damage abnormal collagen from the base of the ulcer and will reduce protease activity (MMPs) by inhibiting the expenditure of $\mathrm{TNF} \alpha$ and increasing angiogenesis which is the activity of macrophags (Gethin 2007). Angiogenesis is considered to help hypoxia problems that are widely found in chronic wounds. Oxygen is required for fibroblast replication, migration, 
performing functions, as well as collagen maturation. Therefore, wound healing will be inhibited in hypoxia (Schreml et al., 2014). According to Marcone (2004), coffee grounds contain calcium. Calcium is known as one of the blood clotting factors (Yusmiati and Wulandari 2017).

According to the research of Maya et al. (2017) which has been modified, and based on the results of the literature study on the effectiveness of MRSA inhibition capability by coffee, the concentration of coffee grounds extract to be used in ointment formulations is 44\%. This can inhibit MRSA growth with the inhibition zone of $14.5 \mathrm{~mm}$ (Pinandito 2018), in ointment preparation $1 \%(\mathrm{w} / \mathrm{w}) .0 .1$ grams of coffee with 10 grams of white vaseline mixed by heating with aqueous ethanol $96 \%$ (Maya et al. 2017).

Based on the data collected, extraction of coffee grounds with soxhlet extraction method is the best method in extracting coffee grounds with $96 \% \quad(\mathrm{v} / \mathrm{v})$ ethanol solvent. Coffee grounds contain natural compounds such as trigonelline, caffeine, and chlorogenic acid that can heal wounds and act as antibacterial substances by inhibiting MRSA growth. Formulation of ointment preparation 1\% (w/w), with 0.1 grams of coffee grounds extract with the concentration of $44 \%$ mixed with vaseline 10 grams, heated together with $96 \%$ ethanol.

\section{ACKNOWLEGDEMENT}

This research was supported by Indonesian Ministry of Research, Technology and Higher Education who provided grant through Program Kreativitas Mahasiswa (PKM).

\section{REFERENCES}

Apriyono A. 2013. Analisis overreaction pada saham perusahaan manufaktur di bursa efek indonesia (BEI) periode 20052009. Jurnal Nomina. 2(2): 76-96

Arimbi D, Yuwono HS. 2016. $\mathrm{pH}$ of wound fluids treated using coffee powder and bacitracin-neomycin powder. Global Journal of Surgery. 4(1): 9-11.

Artho NL, Wuisan JA, Najoan. 2015. Efek serbuk kopi robusta (Coffea canephora) terhadap penyembuhan luka insisi pada kelinci. Jurnal eBiomedik. 3(3): 743748 .

Badan Pusat Statistik. 2017. Statistik Kopi Indonesia. Edisi ke-1. Badan Pusat Statistik. Jakarta. ID.

Belay A, Gholap AV. 2009. Characterization and determination of chlorogenis acids (CGA) in coffee beans by UV-Vis spectroscopy. African J. of Pure and App. Chem. 3(11): 234-240.

Bonyanian Z. dan RB.Rose'Meyer. 2015. Caffeine and its potential role in attenuating impaired wound healing in diabetes. Journal of Caffeine Research. 5(4):141-148.

Chismirina S, Andayani R, Ginting R. 2014. Pengaruh kopi arabika (Coffea arabica) dan kopi robusta (Coffea canephora) terhadap viskositas saliva secara in vitro. Cakradonya Dent J. 6(2):678744.

Dewi VN, Fajaryanti N, Masruriati E. 2017. Perbedaan kadar kafein pada ekstrak biji, kulit buah dan daun kopi (Coffea arabica L.) dengan metode spektrofotometri UV-VIS. Jurnal Farmasetis 6(2):29 - 38.

Farah A. 2012. Coffee :Emerging Health Effects and Disease Prevention. $1^{\text {st }}$ Edition. New Jersey (US): WileyBlackwell Publising Ltd.

Gethin G. 2007. The significance of surface $\mathrm{pH}$ in chronic wounds. Wounds 3(3) : 52-56.

Hajimohammadi K, Makhdoomi K, Zabihi RE, Parizad N. 2019. NPWT:a gate of hope for patients with diabetic foot ulcers. Br. J. Nurs. 28(12):6-9. 
Hati SW, Novita C. 2018. Comparison of market performance on retail business in traditional markets before and after the existance of modern alfamart market and indomaret market in Batam City District Batam City. Adbispreneur. 3(1): 1-21.

Hayati DN, Listyani IL, Salsabila N, Iswara A, Nasruddin. 2019. Kombinasi cold plasma dengan madu sebagai metode penyembuhan luka diabetes melitus. Di dalam: Hayati, editor. The $10^{\text {th }}$ University Research Colloqium 2019 : Bidang MIPA dan Kesehatan. 2019 Okt 28. Gombong, Indonesia. Gombong: hlm 802-807. .

Juliantari NPD, Wrasiati PD, Wartini NM. 2018. Karakteristik ekstrak ampas kopi bubuk robusta (Coffea canephora) pada perlakuan konsentrasi pelarut etanol dan suhu maserasi. Jurnal Rekayasa dan Manajemen Agroindustri. 6(3): 243-249.

Kaisangsri N, Selamassakul O, Sonklin C, Laohakunjit N, Kerdchoechuen O, Rungruang R. 2019. Phenolic compounds and biological activities of coffee extract for cosmetic product. Journal of Science and Engineering. 1(1): 71-76.

Lamona A, Nurman S. 2018. Studi awal komponen minyak biji kopi arabika (Coffea arabica L.) dari Kabupaten Bener Meriah, Provinsi Aceh menggunakan GC-MS. Agriovet. 1(1): 62-72.

Lee B, Lee DG. 2018. Depletion of reactive oxygen species induced by chlorogenic acid triggers apoptosis-like death in Escherichia coli. Free Radic Res. 52(5):605-615.

Mangiwa S, Futwembun A, Awak PM. 2015. Kadar asam klorogenat (CGA) dalam biji kopi arabika (Coffea arabica) asal Wamena, Papua. Jurnal Ilmiah Pendidikan Kimia "Hydrogen”. 3(2): 313-317.
Matheson, E.M., A.G.Mainous, C.J.Everett, D.E.King. 2011. Tea and coffee consumption and MRSA nasal carriage. Annals od Family Medicine. 9(4): 299-304.

Maya SMG, Putri RRF, Sahara A, Ashari GA, Zaky A, Andrianto D. 2017. Comparison of methods for glucosamine production from Achatina fulica shells waste. Current Biochemistry. 4(1):1-8.

Ningsih R. 2014. Pengaruh suhu dan waktu penyeduhan teh celup terhadap kadar kafein [Thesis]. Surakarta (ID): Universitas Muhamadiyah Surakarta.

Paju N. 2013. Uji efektivitas ekstrak daun binahong (Anredera cordifolia (Ten.) Steenis) pada kelinci (Oryctolagus cuniculus) yang terinfeksi bakteri Staphyloccus aureus. Jurnal Ilmiah Farmasi. 2(1):55-60.

Pinandito YKA. 2018. Aktivitas ekstrak biji robusta (Coffea canephora) sebagai antibakteri pada bakteri Escherichia coli, Staphylococcus aureus dan Methicillin-Resistant Staphylococcus aureus (MRSA) [Thesis]. Surabaya (ID): Universitas Airlangga.

Rahardjo, P. 2012. Panduan Budidaya dan Pengolahan Kopi Arabika dan Robusta. Edisi ke-1. Penebar Swadaya. Jakarta. ID.

Ramadhani P, Erly, Asterina. 2017. Hambatan ekstrak etanol rimpang kunyit (Curcuma domestica V.) terhadap pertumbuhan bakteri Staphylococcus aureus secara in vitro. Jurnal Kesehatan Andalas. 6(3):590-595.

Rosa SK, Udiyono A, N Kusariana LD, Saraswati. 2019. Faktor-faktor yang berhubungan dengan timbulnya diabetes pada pasien diabetes mellitus di RSUD K.R.M.T. Wongsonegoro Semarang. Jurnal Kesehatan Masyarakat. 7(1): 192-202.

Sabarni, Nurhayati. 2018. Analisis kadar kafein dalam minuman kopi khop Aceh 
dengan metode spektroskopik.

Lantanida Journal. 6(2): 103-202.

Sativa, O., Yuwana, Bonodikun. 2014. Karakteristik fisik buah kopi, kopi beras dan hasil olahan kopi rakyat di Desa Sindang Jati, Kabupaten Rejang Lebong. Jurnal Agroindustri. 4(2):6577.

Schreml S, Meier RJ, Kirschbaum M, Kong SC, Gehmert S, Felthaus O, Küchler S, Sharpe JR, Wöltje K, Weiß KT et al. 2014. Luminescent dual sensors reveal extracellular $\mathrm{pH}$-gradients and hypoxia on chronic wounds that disrupt epidermal repair. Theranostics. 4(7):721-35.

Scobie, IN. 2007. Atlas of Diabetes Mellitus. $3^{\text {rd }}$ Ed. London: Informa UK.

Siahaan W, Suntari R. 2019. Pengaruh aplikasi kompos ampas kopi terhadap perubahan sifat kimia andisol Ngabab, Kabupaten Malang. Jurnal Tanah dan Sumberdaya Lahan. 6(1): 1123-1132.

Sri T, Rubiyanti R. 2012. Pengaruh pemberian ekstrak biji kopi arabika (Coffea arabica L.) terhadap histopatologi lambung tikus putih galur wistar. Fitofarmaka Jurnal Ilmiah Farmasi.10(1) : 32-41.

Sua'rez-Quiroz ML, Campos AA, Alfaro GV , Gonza'lez-Ri'os O , Villeneuve P, Figueroa-Espinoza MC. 2014. Isolation of green coffee chlorogenic acids using activated carbon. Journal of Food Composition and Analysis. 33: 55-58.

Sutjahjo A. 2013. Kuman dan Uji kepekaan Antibiotik. Indo. J. of Clin. Pathology and Med. Lab. 20(1).

Suwiyarsa IN, Nuryanti S, Hamzah B. 2018. Analisis kadar kafein dalam kopi bubuk lokal yang beredar di Kota Palu. J. Akademika Kim. 7(4):189-192.

Syakfanaya AM, Saputri FC, Mun'im A. 2019. Simultaneously extraction of caffeine and chlorogenic acid from Coffea canephora bean using natural deep eutectic solvent-based ultrasonic assisted extraction. Pharmacon. 11(2): 267-271.

Tanauma HA. 2016. Aktivitas antibakteri ekstrak biji kopi robusta (Coffea canephora) terhadap bakteri Escherichia coli. Pharmacon. 5(4):243-251.

Tello J, Viguera M, Calvo L. 2011. Extraction of caffeine from Robusta coffee (Coffea canephora var. Robusta) husks using supercritical carbon dioxide. The Journal of Supercritical Fluids. 59(2011): 53-60.

Utami NF, Nhestricia N, Maryanti S, Tisya T, Maysaroh S. 2018. Uji aktivitas antioksidan dari biji kopi robusta (Coffea canephora P.) berdasarkan perbedaan ekologi dataran tinggi di pulau jawa. Fitofarmaka Jurnal Ilmiah Farmasi. 8(1): 67-72.

Wahyuni, A. dan Arisfa N. 2015. Senam kaki diabetes efektif meningkatkan ankle brachial index pada pasien diabetes melitus tipe II. Ejournal Keperawatan. 5(1): 1-11.

Wigati EI, Pratiwi E, Nissa TF, Utami NF. 2018. Uji karakteristik fitokimia dan aktivitas antioksidan biji kopi robusta (Coffea canephora L.) dari Bogor, Bandung dan Garut Dengan metode DPPH (1,1-diphenyl-2-picrylhydrazyl). Fitofarmaka Jurnal Ilmiah Farmasi. 8(1): 59-66.

Winarsih W, Wientarsih I, Sutardi LN. 2012. Aktivitas salep ekstrak rimpang kunyit dalam proses penyembuhan luka pada mencit yang diinduksi diabetes. Jurnal Veteriner.13(2):242-250.

Xie Y, Yang W, Tang F, Chen X, Ren L. 2014. Antibacterial activities of flavonoids: structure-activity relationship and mechanism. Curr. Med. Chem. 22(1): 132-149.

Yisak H, Redi-Abshiro M, Chandravanshi BS. 2018. Selective determination of caffeine and trigonelline in aqueous extract of green coffee beans by FT- 
MIR-ATR spectroscopy. Vibrational Spectroscopy. 97(2018):33-38.

Yusmiati SN, Wulandari RE. 2017. Pemeriksaan kadar kalsium pada masyarakat dengan pola makan vegetarian. Jurnal SainHealth. 1(1):4349. 